\title{
The Shift of Mangrove Ecosystem Coverage Based on its Health Condition in the Coastal Area of Semarang and Demak Central Java Indonesia
}

\author{
${ }^{1}$ Sri Puryono, ${ }^{2}$ Suryanti Suryanti, ${ }^{3}$ Rini Budi Hastuti and ${ }^{4}$ Sakina Rosellasari \\ ${ }^{1}$ Regional Secretary, Province of Central Java, Indonesia \\ ${ }^{2}$ Faculty of Fisheries and Marine Science, \\ ${ }^{3}$ Faculty of Science and Mathematics, Diponegoro Universit Semarang, Indonesia \\ ${ }^{4}$ Marine and Fisheries Service, Province of Central Java, Indonesia
}

\begin{abstract}
The condition of mangrove ecosystem is fluctuated due to the various factors such as the environmental support, replanting, maintenance, natural disturbance and anthropogenic effects. This research aimed to understand the change of mangrove coverage between 2011 and 2016 in Semarang and Demak and analyze the change of mangrove proportions based on the damage level. The research was conducted in October 2017 through literature study to obtain information of the condition of mangrove ecosystem in Semarang city and Demak Regency in 2011 and 2016. Data analysis was conducted with Chi-square test to understand the change of coverage proportion based on the degradation level. The result shows that the mangrove coverage of Demak Regency was increased from 3.950 ha in 2011-4.595 ha in 2016 while the coverage in Semarang city was static with 325 ha. Increased mangrove coverage was occurred in Demak and Semarang both for the good and poor condition of mangrove. Contrarily, the coverage of mangrove with moderate condition was reduced. Statistically, the proportions of mangrove conditions were significantly different. Mangrove coverage in Demak and Semarang should be improved to recover the mangrove ecosystem which has been destructed.
\end{abstract}

Key words: Coverage, degradation, improvement, maintenance, mangrove, ecosystem

\section{INTRODUCTION}

The coastal area of Semarang city and Demak Regency are among the most vulnerable regions to soil erosion in Central Java (Marfai, 2014). The coastal erosion has changed the coastline to $500 \mathrm{~m}$ backward in Semarang city (Marfai, 2017) while in Demak Regency the coastline has been regressed to nearly $5 \mathrm{~km}$. Thus, massive loss of ecosystems and civilizations were occurred in both regions.

Mangrove forest in the coastal area is an important ecosystem which supports the livelihood of both coastal and terrestrial organisms. However, the condition of mangrove ecosystem in many regions is now degraded. Various factors have triggered the degradation of mangrove ecosystem. Among the various factors affecting mangrove ecosystem, human interest is the major factor which caused mangrove degradation (Rasyid et al., 2016). Rapid development in the coastal area has caused several problems to the environment due to the change of land use as well as the increasing human activities.
Mangrove has important role in the maintenance of coastal area, especially, in the developed area. Mangrove ecosystem provides various benefits such as to control climate as barrier to protect coastal area from storms and erosion, maintain the water quality, provide various fish resources to support the livelihoods of coastal communities (Orchard et al., 2015). The issues concerning mangrove ecosystem change over times. In the early past, decades in order to improve the rehabilitation effort, mangrove was much related to the fisheries sector. Some research tried to prove the impact of mangrove coverage to the abundance of fish stocks (Anneboina and Kumar, 2016; Yulianto et al., 2016). But now a days the economic valuation of mangrove has been calculated including the consideration of its ecological services (Salem and Mercer, 2012). The result shows that mangrove provides much more economic preservation and benefits as a preserved ecosystem than being utilized intensively.

One of the most known phenomena which affect the coverage of mangrove is the global climate change. Global climate change causes the rise of sea level which further affect the coverage of mangrove due to the increasing

Corresponding Author: Sri Puryono, Regional Secretary, Province of Central Java, Indonesia 
inundation in the mangrove ecosystem (Marfai, 2014). However, the change of land use also has significant contribution on the change of mangrove coverage, due to the conversion for various purposes such as fishpond and settlement (Rasyid et al., 2016).

Even though conversion of mangrove forest to fishpond provides economic benefit but the benefit is not sustainable. A case study conducted in Demak Regency showed that decreased mangrove coverage along with increased fishpond area caused coastal erosion, decreased pond width and decreased pond productivity as well as its profitability (Romadhon et al., 2014).

Mangrove degradation also, affects the social condition of coastal community such as increasing poverty and expanding slump area. However, both conditions are existed in the coastal area of Demak Regency and Semarang city (Sekatia, 2015; Siti et al., 2015). The long impact of mangrove degradation is the reduction of resources. As the impact, a lot of the coastal community which is dominated by fishermen lost their employment. At the same time, the loss of mangrove also causes another environmental problems including frequent flood, storms and increasing pollutant concentration.

In order to maintain the sustainability of coastal ecosystem as well as the resources, conservation of mangrove ecosystem is strongly required, especially, in the regions in which previously inhabited by mangrove. However, the effort requires the participation of the related stakeholders such as the government, NGO as well as the local community (Orchard et al., 2015). The effort to promote mangrove plantation has been conducted both in Semarang and Demak. In Semarang, rehabilitation of mangrove is conducted through the development of breakwaters and plantation of mangrove in the coastal area (Hartati et al., 2016).

Even though mangrove has various benefits to the coastal ecosystems but the function is not absolute. Mangrove requires the support of another ecosystems to provide optimum function to the resources (Lee et al., 2014). Moreover, the condition of mangrove ecosystem also has significant role in the establishment of ecological services. The capacity of mangrove in supporting the coastal resources or in protecting coastal area might be reduced due to the poor condition of mangrove ecosystem. Mangrove condition fluctuates based on the disturbance and maintenance it achieved which may impact the services it provide.

The monitoring of mangrove coverage and health is needed to evaluate the impact of human activities on the coastal ecosystem (Cummings and Shah, 2018). This research aimed to: understand the change of mangrove coverage between 2011 and 2016 in Semarang and Demak and analyze the change of mangrove proportions based on the damage level.

\section{MATERIALS AND METHODS}

The research was conducted in October 2017 including the area of interest in Semarang city and Demak Regency. The area in interest of this research is shown in Fig. 1.

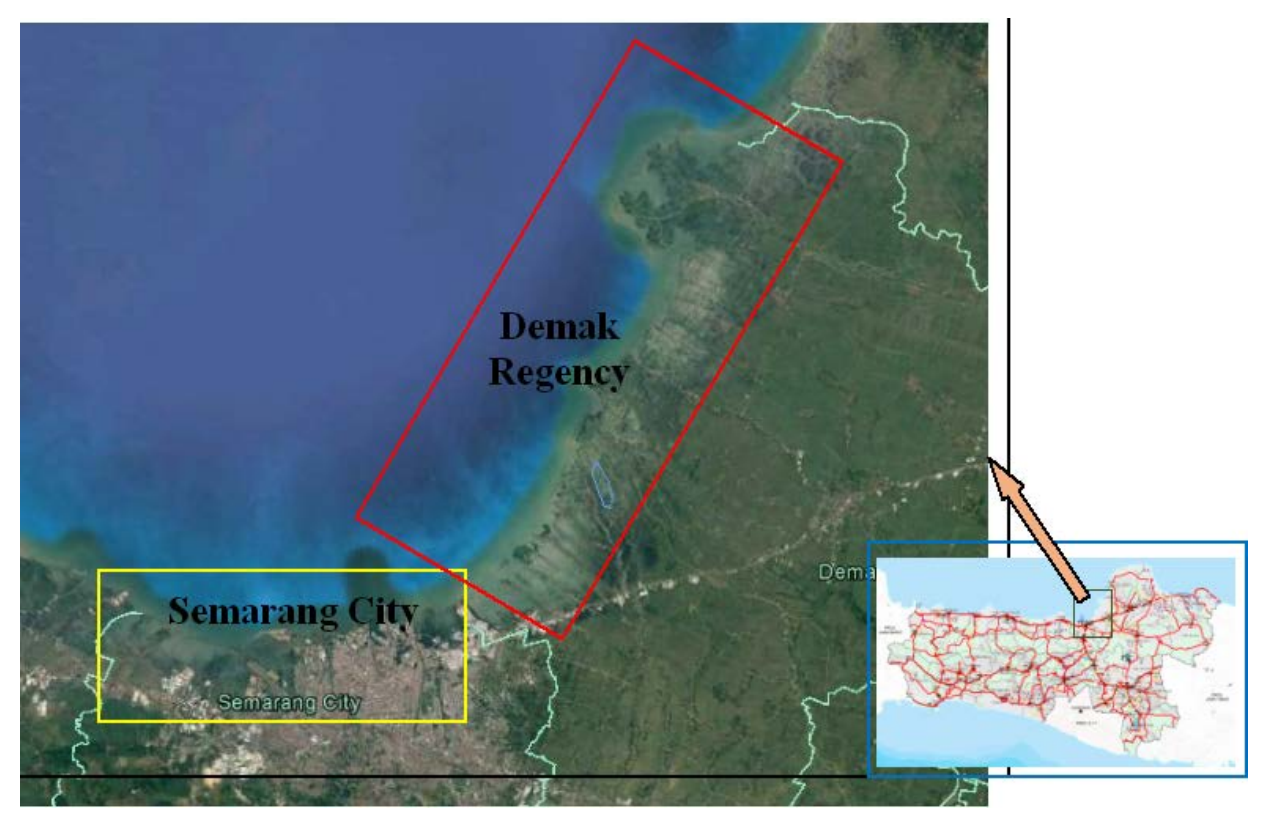

Fig. 1: Area of interest of the research 
The primary data was collected through literature study. The collection of reference was obtained from the Fisheries and Marine Services of Central Java. Since, the research aimed to compare the condition of mangrove within the last 5 years, data collection was only selected for year 2011 and 2016. However, detailed information on the degradation level of mangrove ecosystem was identified including good, moderate and poor condition.

Data processing was conducted to calculate the change of mangrove coverage particularly for each degradation level and total coverage in each region. Relative percentage of coverage change was calculated referred to initial total coverage. Data analysis was conducted through Chi-square analysis to compare, if the proportion of mangrove condition was similar. Statistical data analysis was conducted with SPSS Statistic with confidence interval of $95 \%$.

\section{RESULTS AND DISCUSSION}

Data collection on the coverage of mangrove ecosystem in Semarang city and Demak Regency showed noticeable difference between both region. The coverage of mangrove in Demak Regency is much wider than the Semarang city. Detailed condition of mangrove coverage in Semarang city and Demak Regency in 2011 and 2016 is presented in Table 1.

Table 1 shows that there was an increase of total mangrove coverage in Demak Regency. There was 644 ha new mangrove coverage in 2016 or $16.3 \%$ from initial coverage in Demak Regency. However, the coverage of mangrove in Semarang city was static. According to the data, there were changes on mangrove condition as well. In Demak, the coverage of mangrove with good condition was increased by $11.6 \%$ or 459.0 ha while in Semarang city increased by 266.3 ha or $81.9 \%$. Both Semarang city and Demak Regency have decreased mangrove coverage with moderate condition and increased coverage of mangrove with poor condition. However, the increasing coverage of poor mangrove condition in Demak Regency was contributed by new mangrove while in Semarang city was contributed by degraded mangrove.
Statistical analysis was conducted through Chisquare test. Analysis was conducted to compare the proportion of mangrove condition between years both for cumulative coverage and partial coverage for each region. Chi-square analysis on the cumulative coverage of mangrove between years showed that there was significant difference of mangrove conditions in 2011 and 2016. Mangrove coverage which has good condition was increased from $47.1-55.7 \%$, represents the coverage increase from 2.015-2.741 ha. Mangrove with moderate condition was decreased from 1.536-977 ha, represents the proportion of 35.9 and $19.9 \%$. While the proportion of mangrove with poor condition was increased from $16.9-24.4 \%$ which represents the increase of coverage from $724-1.203$ ha. Chi-square analysis resulted $\div 2$ value of 310.387 and probability of 0.000 which indicates that the coverage of mangrove of 2011 and 2016 was significantly different.

Analysis on the mangrove coverage in Semarang showed that the change of mangrove condition was significant. Mangrove with good condition increased from $1.2-82.9 \%$ within 5 years including the coverage increase from 4-271 ha. The increase of good mangrove coverage seems to be the shift of moderately damaged mangrove which was decreased from $95.4 \%$ to only $8.3 \%$ which represents the coverage of 310-27 ha. Unfortunately, there was also a decrease of mangrove condition from moderate to poor as shown by the proportion of poor mangrove condition from $3.4-8.9 \%$ which represents the coverage or 11 and 29 ha. Statistical analysis resulted $\div 2$ value of 504.984 and probability of 0.000 indicating the significant change of degradation level.

The change of mangrove condition in Demak Regency was also significant. The statistical analysis showed the result of $\div 2$ value of 146.941 with probability of 0.000 . Thus, the proportion of each damage level has changed significantly. The coverage of mangrove with good condition was increased from 2.011-2.470 ha which represents the proportion of 50.9 and $53.8 \%$. The coverage with moderate damage was decreased from $31.0-20.7 \%$ which represents the coverage of 1.226 ha and 950 ha while the poor mangrove condition was increased from 713-1.174 ha which represents the proportion of 18.1 and $25.6 \%$.

Table 1: Change of mangrove coverage in Semarang city and Demak Regency between 2011 and 2016

\begin{tabular}{|c|c|c|c|c|c|c|c|c|}
\hline \multirow[b]{2}{*}{ Mangrove condition } & \multicolumn{4}{|c|}{ Demak Regency } & \multicolumn{4}{|c|}{ Semarang city } \\
\hline & 2011 & 2016 & Change & Percent change & 2011 & 2016 & Change & Percent change \\
\hline Good & $2,011.0$ & $2,470.0$ & 459.0 & 11.6 & 4.000 & 270.3 & 266.3 & 81.9 \\
\hline Moderate & $1,226.0$ & 950.0 & -276.0 & -7.0 & 310.0 & 26.40 & -283.6 & -87.3 \\
\hline Poor & 713.0 & $1,174.0$ & 461.0 & 11.7 & 11.00 & 28.30 & 17.3 & 5.3 \\
\hline Total & $3,950.0$ & $4,594.0$ & 644.0 & 16.3 & 325.0 & 325.0 & 0.0 & 0.0 \\
\hline
\end{tabular}

Statistik Kelautan, Pesisir dan Pulau-Pulau Kecil, Fisheries and Marine Services of Central Java (2011, 2016) 
According to the result, the condition of mangrove coverage in Semarang city and Demak Regency was considered as improved, since, large proportion of mangrove with moderate condition shifted into good condition during 2011 and 2016. Moreover, there was an increase in total coverage of mangrove in Demak Regency which shows that rehabilitation of mangrove is still on progress. Unfortunately, the coverage of mangrove in Semarang city was static.

The change of mangrove coverage as well as its degradation levels could be caused by various factors such as the impact of sea level rise (Marfai, 2014) or intended clearing for settlement or fishpond (Rasyid et al., 2016). However, removal of mangrove is also frequently occurred to provide space for tourism and fishing activities (Dencer-Brown et al., 2018).

The loss of mangrove forest in Demak particularly within the last decade was caused by sea level rise (Marfai, 2014). However, human intervention also has significant contribution to the degradation of mangrove forest in Demak. Massive conversion of mangrove to shrimp ponds was the main factor which caused significant reduction of mangrove coverage (Abdul et al., 2012). However, the development of commercial port in Semarang city also has the significant contribution which emphasized the mangrove destruction due to the change of tidal current. The combination of mangrove removal and the change of the pattern of longshore current in Demak Regency caused the increase of coastal erosion rates. Further, impact was increased inundation and the change of coastline.

Conversion of mangrove forest to another utilization such as fishpond and settlement had been occurred for decades (Rasyid et al., 2016). The impact is the decreased mangrove coverage along with the increasing coverage of fishpond and settlement. However, the conversion which is motivated by economic objectives seems to be more dominant. The growth of human population is generally slow, thus, the conversion rate was low. But the interest in mangrove utilization for economic related activities is several fold (Rasyid et al., 2016).

The degradation of mangrove forest in Semarang city was dominated as the impact of environmental change. Increasing coastal erosion, sea level rise and land subsidence were considered as the main factor affecting the degradation of coastal area (Hartati et al., 2016). Increased environmental stress in the coastal area of Semarang city was considered as the impact of increasing coastal and upland development. Thus, the ecological balance is disturbed.

The natural expansion of mangrove forest occurred due to the increased sedimentation in the estuaries
(Dencer-Brown et al., 2018). The accumulated sediment improves the chance for mangrove seedlings to settle down and established. Thus, little by little mangrove moves forward to the sea. However, the expansion rate varies between regions due to the difference of sediment balance (erosion-sedimentation).

Increased mangrove coverage in Demak Regency is supported by its environmental condition. Semarang city only has the coastline of $45.72 \mathrm{~km}$ (Supriharyono and Agus, 2013) while Demak Regency has the length of $57.8 \mathrm{~km}$ (Laksmi et al., 2015). Thus, there is significant difference in the length of coastline in Semarang and Demak. Moreover, the land-use in the coastal area of Semarang city is dominated with industries and settlements while Demak is dominated by inundated area due to massive erosion of the previous decades. Thus, the chance of mangrove expansion is better in Demak Regency.

The static mangrove coverage in Semarang city is considered as the impact of limited available coastal area. However, the improvement of mangrove condition should improve the environmental services it provides. Thus, improvement on the mangrove quality is preferred than trying to expand the mangrove area. Ecosystem maintenance is also important for mangrove forest in Semarang city, since, the pressure from industrial and anthropological activities keeps increasing. Without appropriate maintenance effort, the ecosystem would be more vulnerable to degradation.

Due to the massive destruction of mangrove forest in Semarang city and Demak Regency, various effort has been conducted to recover mangrove coverage. Planting of mangrove trees has been conducted for years. In Demak, planting is supported by NGO OISCA. The impact of the activity includes the improvement of mangrove condition and expanded mangrove coverage. However, the main purpose of the replanting activity is emphasized to recover lost mangrove area.

Mangrove replanting is also conducted in the coastal area of Semarang city. However, the replanting activity in Semarang is proposed to reduce the ecological impact of industrial and anthropogenic activities (Hartati et al., 2016). Unfortunately, since, the coastal area of Semarang city is mostly allocated as industrial area, the available space for mangrove planting is limited.

In order to improve the effectiveness of mangrove planting, another efforts are conducted in both regions. The developments of breakwaters are applied to reduce sediment dynamic in the coastal area (Hartati et al., 2016; Putri and Muskananfola, 2014). Thus, the accumulation 
rate of the sediment could be increased, providing space for mangrove settlements. The application of breakwaters in both regions seems to be effective in reducing coastal abrasion and increasing sedimentation.

Increased mangrove coverage in both regions should improve the coastal environment quality and services (Quinn et al., 2017). The improvement of mangrove ecosystem condition should also improve the biodiversity both in the terrestrial and coastal water (Dencer-Brown et al., 2018). Mangrove provides various services to the coastal ecosystem including the protection against flood and storm, control the flow and sediment transport, maintaining water quality, provide nutrient pool, habitat and nursery area for plants and animals, source of biodiversity, etc., (Salem and Mercer, 2012). Thus, increasing mangrove coverage means that the services it provides would be emphasized.

Fisheries is one of the most affected sector due to the improvement of mangrove quality in the coastal area. Mangrove ecosystem supports the abundance and biodiversity of fish in the coastal area. Thus, the potential of utilization is as well increased. However, Demak Regency had the wider mangrove coverage as well as the improved mangrove coverage. Thus, the potential of mangrove in supporting fisheries resources should be greater than Semarang city. In the meanwhile, even though there was an improvement of mangrove condition in Semarang city but the total coverage was static which indicates that the potential is limited as well.

Economically, improvement of mangrove quality can increase the income of fishermen (Herwindya and HS, 2014). The economic benefits are not only considered as economic income to the fishermen but also the reduction of maintenance cost of the environment and reduction of fishing costs. In this case, economic benefit is achieved ecological impact of mangrove.

Even though current conditions of mangrove ecosystem in Semarang city and Demak Regency is improved but the threat still remains. Mangrove ecosystem is vulnerable to conflict of interest. Many stakeholders are trying to get involved in the utilization or exploitation of mangrove ecosystem. Thus, management policy plays important role in the management and maintenance of mangrove sustainability (Ferreira and Lacerda, 2016).

The improvement in mangrove coverage as well as its quality is required to prevent the damage of the coastal ecosystem (Marfai, 2014). However, the application should consider some other factor such as the coastal ecology and the land land use. Moreover, the same management strategy may have different impact on the mangrove rehabilitation. Thus, different region may require different policy on the management of coastal area.

The condition of mangrove forest including the health and coverage should be monitored continuously to keep the track of mangrove changes (Cummings and Shah, 2018). Potential threat should be identified as well, both major and minor threat (Manjari and Aswin, 2016). Compared to the anthropogenic impacts, the sea level rise is considered to have minor impact on mangrove ecosystem. The major threats include the conversion of mangrove forest for agriculture and aquaculture purposes. Thus, the utilization of coastal area should be well regulated. Otherwise, repeated history may occur where the loss of mangrove coverage caused multiplied multi-sector impact on the coastal area. However, anthropogenic activity also causes the increase of pollution and siltation which is considered as more threatening (Saha et al., 2017). Now a days, another threat arises due to the utilization of mangrove as tourism interest. Mangrove tours causes the destruction of mangrove area including the activity of wood cutting and development of tourism facilities (Nagi and Abubakr, 2013).

The management of mangrove forest should involve the participation of local community, since, it is the most dominant stakeholder which receive benefit from the recovered ecosystem (Agungguratno and Darwanto, 2017). Generally, the awareness of coastal community on the importance of mangrove ecosystem is low. Some of them considered the participation as commercial service. They do not will to participate unless they get paid. Thus, the participation of local community is considered as complex path way in the management of mangrove forest. The low participation could be caused by community's lack of knowledge concerning the economic benefit of mangrove (Abdullah et al., 2014). Thus, education is needed to encourage the community's knowledge and participation in the conservation of mangrove ecosystem (Sawairnathan and Halimoon, 2017).

The exploitation of mangrove ecosystem frequently arises conflict of interest among sectors. Thus, conservation is considered to provide more economic value than destructive exploitation (Lopez-Angarita et al., 2016). The actors of interest of mangrove include: the government, education institution, fisherman (fisheries), agriculture, environmentalist, planning and development agents, tourisms, conservancy and NGOs (Asihing, 2014). Mangrove ecosystems in Semarang city and Demak Regency are developed from the replanting activities due to massive destruction in the previous decades. Thus, 
the compositions of mangrove species are limited. Well developed mangrove ecosystem should consist of many other mangrove species. However, originally there are a lot of mangrove species in both location. Thus, further effort should be conducted to improve the diversity of mangrove species.

\section{CONCLUSION}

There was an increase of total mangrove coverage as much as $16.3 \%$ in the coastal area of Demak Regency between 2011 and 2016 while the coverage in Semarang city was static. Generally, mangrove with moderate condition shifted to good condition both in Semarang and Demak, however, in Semarang city there was also degradation of mangrove coverage from moderate to poor condition even though the proportion was small. The proportions of mangrove conditions were significantly different. In Demak, the change was contributed by the shift of mangrove from moderate to good condition which caused the decrease of the proportion of mangrove with moderate condition while the increase of mangrove proportion with poor condition was contributed by new coverages. In Semarang, significant shift occurred from mangrove with moderate condition which was dominating to mangrove with good condition. Proposed management of mangrove ecosystem in Demak Regency is to improve the coverage as well as the condition of mangrove while in Semarang city, since, the area is limited the existing coverage should be optimized.

\section{ACKNOWLEDGEMENT}

The researchers would like to thank the Head Office of Marine and Fisheries Service, Province of Central Java Indonesia for data support and field assistance during the research.

\section{REFERENCES}

Abdul, C.M., P. Rudhi and D.S.A. Agus, 2012. [Study of changes in mangrove land area in Bedono Village, Sayung District, Demak Regency using Ikonos Satellite images in 2004 and 2009 (In Indonesian)]. J. Mar. Res., 1: 167-173.

Abdullah, K., A.M. Said and D. Omar, 2014. Community-based conservation in managing mangrove rehabilitation in Perak and Selangor. Procedia Soc. Behav. Sci., 153: 121-131.

Agunggunanto, E.Y. and D. Darwanto, 2017. [Strengthening the mangrove ecosystem for economic empowerment of coastal communities (In Indonesian)]. Eko. Reg. J. Econ. Dev. Area, 11: $1-9$.
Anneboina, L.R. and K.S. Kumar, 2016. Contribution of mangroves to marine fisheries in India. MSc Thesis, Madras School of Economics, Chennai, India.

Asihing, K., 2014. Actor, interest and conflict in sustainable mangrove forest management-a case from Indonesia. Intl. J. Mar. Sci., 4: 150-159.

Cummings, A.R. and M. Shah, 2018. Mangroves in the global climate and environmental mix. Geogr. Compass, 12: e12353-e12353.

Dencer-Brown, A.M., C.A. Andrea, M. Simon and P. John, 2018. A review on biodiversity, ecosystem services and perceptions of New Zealands mangroves: Can we make informed decisions about their removal? Resour., 7: 1-21.

Ferreira, A.C. and L.D. Lacerda, 2016. Degradation and conservation of Brazilian mangroves, status and perspectives. Ocean Coastal Manage., 125: 38-46.

Hartati, R., R. Pribadi, R.W. Astuti and R. Yesiana, 2016. [Study of safeguarding and protection of beaches in coastal areas of Tugu and Genuk Sub-district, Semarang city (In Indonesian)]. Trop. Mar. J., 19: 95100 .

Herwindya, A.Y. and E.W. HS, 2014. Analysis of the benefits of mangrove forests and coral reefs on the coastal environment and their implications for fishermens income (study on the Demak coastal coast). J. Accounting, Manage. Econ., 21: 1-16.

Laksmi, L.D., A. Ghofar and D. Wijayanto, 2015. [Analisis Bioekonomi Rajungan Perikanan (Portunus pelagicus) in the waters of Demak (In Indonesian)]. J. Water Resour Manage., 4: 145-149.

Lee, S.Y., J.H. Primavera, F. Dahdouh-Guebas, K. McKee and J.O. Bosire et al., 2014. Ecological role and services of tropical mangrove ecosystems: A reassessment. Global Ecol. Biogeogr., 23: 726-743.

Lopez-Angarita, J., C.M. Roberts, A. Tilley, J.P. Hawkins and R.G. Cooke, 2016. Mangroves and people: Lessons from a history of use and abuse in four Latin American countries. For. Ecol. Manage., 368: 151-162.

Manjari, N.E. and A. Aswin, 2016. A study on threats and sustainability of mangrove vegetation in India. SSRG. Intl. J. Geo Inf. Geol. Sci., 3: 15-20.

Marfai, M.A., 2014. Impact of sea level rise to coastal ecology: A case study on the Northern part of Java Island, Indonesia. Quaestiones Geographicae, 33: 107114.

Marfai, M.A., 2017. The hazards of coastal erosion in Central Java, Indonesia: An overview. Geografia Malaysian J. Soc. Space, 7: 1-9.

Nagi, H.M. and M.M. Abubakr, 2013. Threats status to the mangrove ecosystem along the coastal zone of Yemen. J. King Abdulaziz Univ. Mar. Sci., 179: 1-34. 
Orchard, S., L. Stringer and C. Quinn, 2015. Environmental entitlements: Institutional influence on mangrove social-ecological systems in Northern Vietnam. Resour., 4: 903-938.

Putri, M.P. and M.R. Muskananfola, 2014. [Hydrooceanographic characteristics and the level of community participation in overcoming coastal damage in Bedono Village, Sayung District, Demak Regency (In Indonesian)]. Manage. Aquat. Resour. J., 3: 225-234.

Quinn, C., L. Stringer, R. Berman, H. Le and F. Msuya et al., 2017. Unpacking changes in mangrove socialecological systems: Lessons from Brazil, Zanzibar and Vietnam. Resour., 6: 1-14.

Rasyid, A., M.A. AS, N. Nurdin and I. Jaya, 2016. Impact of human interventions on mangrove ecosystem in spatial perspective. IOP. Conf. Ser. Earth Environ. Sci., 47: 1-7.

Romadhon, A., D. Hastuti and R. Prabowo, 2014. Effect of rob and abrasion on the income of milkfish farmers (case study of Sidogemah Village, Sayung District, Demak District, Central Java). Mediagro, 10: 69-81.

Saha, A., R.C. Tanmay, Z. Sufia, P. Prosenjit and S. Abhishek et al., 2017. Evaluating and ranking the threats in the Indian mangrove forest adjacent to Bangladesh Sundarbans. Org. Med. Chem., 2: 1-4.
Salem, M.E. and D.E. Mercer, 2012. The economic value of mangroves: A meta-analysis. Sustainability, 4: 359383.

Sawairnathan, M. and N. Halimoon, 2017. Assessment of the local communities knowledge on mangrove ecology. Intl. J. Hum. Capital Urban Manage., 2: 125138.

Sekatia, A., 2015. [Study of slum settlements and tambak lorok fishermen Semarang case study of community participation]. Modul, 15: 57-66.

Siti, A.M., R. Gamal and M. Chatarina, 2015. Analysis of settlement changes and characteristics of slum settlements due to abrasion and inundation in Sayung coastal area, Demak Regency, 2003-2013. GeoEco, J., 1: 83-100.

Supriharyono, S. and H. Agus, 2013. [Impact of coastline dynamics using multi-temporal satellite imagery at Semarang Beach, Central Java Province]. Saintek Perikanan J., 8: 33-37.

Yulianto, G., K. Soewardi and L. Adrianto, 2016. The role of mangrove in support of coastal fisheries in Indramayu Regency, West Java, Indonesia. AACL. Bioflux, 9: 1020-1029. 